\title{
Classification of small scale landforms, its significance: a case study of the middle Ichamati river, India
}

Landforms are the core concept of geomorphology. The definition of landforms, their characterization and classification are the core subject of geomorphology. But all these become complex when it seems to difficult to identify the landforms, especially when the area is plain land and highly modified by human activities. This paper has examined the characters of the landforms of the middle basin of the Ichamati river, the important distributary in the district of North 24 Parganas, India. It has been primarily taken an attempt to classify the landforms with the help of the satellite image, IRS P6 LISS II and LISS III. The DEM is not enough to identify the micro scale landform. To overcome this difficulty a series of field works have been conducted (2002, 2004, 2012 and 2015). The landforms have been classified according to second order derivative (Wood, 1996) method. Then ANOVA test has been applied to justify the classification. The F-statistics have indicated the effort is satisfying. The changing character of different landforms denote the river is going to be deteriorating from downstream to upward.

Keywords: Landforms, geomorphology, classification, DEM, fieldwork, second order derivative, ANOVA.

\subsection{Introduction}

$\mathrm{T}$ The analysis of landform is a lost art and seems to have become part of the drop-out concept of geomorphic thinking (Fryirs 2016) though it is a relevant issue for mapping and hazards analysis (Darmis 1991). Landforms are the $4 \mathrm{D}$ forms and $3 \mathrm{D}$ forms can be defined as a specific geomorphic features on the earth surface (Goudie 2004), ranging from large-scale to minor features (Slaymaker et al. 2011, Blaszezynski 1997). The study of landforms appears as the central or core concept of geomorphology (Thorn 1978), deal with specific geomorphic process (Crevenna et al. 2005). Landforms reflect the combine interaction of geology, change of climate (Garavaglia et al. 2009), time and biota also (Brierley et al. 2013; Dietrich and Perron 2006; Piacente 2003).

$\overline{\text { Blind peer reviews carried out }}$

Mr. Madhab Mondal, Assistant Professor, Basirhat College, Dept of Geography, Basirhat, North 24 Parganas, West Bengal, India. E-mail: Madhabmonda12009@gmail.com
Geomorphology is concerned with the study of evolution of erosional landforms (Small 1978), interpretation of the forms rather than the process (Wooldridge and Morgan 1959) because geographically-trained geomorphologist are not well qualified to work in the field of process (Strahaler 1969). However, in the broader sense the constructional or depositional landforms have been included within the sphere of geomorphology (Small 1978). In the study of landform, there are two connotations, geomorphology and geomorphometry with sharp distinction. Geomorphology concerns with the study of form 'morphos' of the land (Thorn 1978), but geomorphometry is a sub discipline of geomorphology having an object of quantitative and qualitative description of landforms (Pike 2000), the geometric interpretation of landform (Angillieri 2008, Mesa 2006, Thorn 1978, Strahler 1964, 1957).

The Geomorphologist vastly studied about the multifaceted classifications of landforms summarized are, based on forms, i.e. convex, concave, rectilinear etc. (Chorley et al. 1984; Thorn, 1978), prototype landforms (Dawkins 2004), composite pro-type (Matthews et al. 2014; Phillips 2009a), gradient (Strahler 1969), extent, i.e megascale, macroscale $(>250 \mathrm{~m})$, mesoscale $(1-250 \mathrm{~m})$ and microscale $(<1 \mathrm{~m})$ (Maschant amd Head 2007); megascale ( $>1000 \mathrm{~km})$, macroscale (100$1000 \mathrm{~km})$, mesoscale (1-100km) (Delcourt and Delcourt 1988); and other (Burr et al. 2009; Soil Survey NSSH 2008; Ford et al. 1989), first order, second order and third order (Chorley et al. 1984), based on climatic region, such as humid, sub- humid etc. (Penck 1924), Cultural landforms (Anghel 2013, Reynards 2004a, Panizza 2001) or constructive and destructive landforms (Bloom 1991, Summerfield 1991).

Geomorphic process being the cascading system, consisted of mass and energy which are directed through different systems (Chorley et al. 1984), among them river is an important molding element (Davis 1899). Nature represents two types of river systems, i.e. contributing river system and distributing river system (Chorley et al. 1984, Sen 1993) or detachment-limited and transport limited (Whipple and Tucker 2002) might have two different types of systemoperation. The philosophy behind the contributing systemoperation is to attain a quasi-equilibrium condition (Langbein and Leopold 1964, Mackin 1948), the equilibrium condition 
(Bloom et al. 2017); a minimum variance (Langbein and Leopold 1966), the concept of entropy in landscape evolution (Leopold and Langbein 1962, Leopold and Wolman 1960). All these models concerns with decreasing height, though errosional process. On the other hand, in the distributing system-operation, rivers always try to increase its energy by depositing its load that represents the negative feedback system indeed (Parkaer and Sutherland 1990, Wilcock and Soutard 1989, Andrews and Parker 1987) and the resultant landforms are the signatures of such effort.

The Ichamati river is a meander river in the GangaBrahmaputra Details (GBD) environment (Mondal et al. 2018, Mondal and Satpati, 2019). After the formation of GBD plain the Ichamati river superimposed on it (Mondal 2010) and produced its associated landforms by lateral accretion, island formation and channel abandonment (Chorley et al. 1984, Rice 1931). The Ichamati river has been bifurcated from the Mathabhanga river, a distributary of the Padma river (Rudra 2014) and subsequently the river has been anthropogenically delinked from the Padma-Mathabhanga-Churni river system in 1970s (Sarkar 2004). So the river gets hardly upstream discharge from its source stream, except rainy season. The Ichamati river has been intensively investigated by Mondal, (2010, 2011a, b); Mondal and Satpati, (2013, 2014, 2015, 2016, 2017, 2019 a, b); Mondal et at. (2016, 2018); Mondal and Bandhyopadhyay (2014, a, b) etc. All the articles have tackled the channel properties such as longitudinal profile, cross sectional properties, hydrodynamics, water quality etc. of the river. Landforms (within the channel and on the surface) produced by the river remain overlooked. This article has attempted to discuss about the landforms of the middle portion of the Ichamati river. The Ichamati river is gradually waning from downstream upward (Mondal et al. 2018), decreases of transport capability downstream upward (Basu and Howlader 2008), 38\% loss of stream energy (Mondal 2016). The upper portion of the river is dead and the lower portion of the river is dynamic (Mondal 2011). The middle portion of the river belongs to the transition zone between these two flow regimes. Therefore, this study can explain how the landforms change spatio-temporal with the change of hydrodynamic of the river.

Traditionally geomorphology is concerned with the mesoscale landforms (Thorn 1978) and these landforms are unexplainable in respect of human lifetime (Chorley et al. 1984; Thorn, 1978). They have a little landform sensitivity (Chorley et al. 1984, Thorn 1978) and a small trigger of geomorphic process is not capable to alter their form immediately. So, it needs a reference of past episode to explain the form of meso-scale landforms (Thorn 1978). The micro-scale land forms have a significant role to overcome such problem because they played a delicate role to balance between form and process and reducing emphasis on the past (Thorn 1978). The objectives of this article are, (a) general discussion of the landforms, (b) the area is highly modified by the human activities. So DEM is not effective to classify the land form in micro level. A detail field survey and statistical analysis have attempted to classify the landforms in micro level, (c) to discuss about the spatio- temporal change of the landforms with the basis of hydrodynamic of the river. This paper is an attempt to discriminate the landforms mainly in the highly modified low-relief area, with a twin-venture of intensive fieldwork and statistical analysis, when DEM is not enough doing it.

The study area has some experiences of flood occurrences in several years, such as, 1802, 1823, 1838, 1857, 1859, 1867, 1871, 1885, 1890, 1936, 1938, 1952, 1955, 1959, 1966, 1970, 1971, 1978, 1984, 1999, 2000, 2004 and 2008 (Mondal et al. 2019). Besides the daunting challenge of flood mitigation there are frequent water logging conditions in the study area due to heavy downpour. This study is an illumination of the geomorphic problems behind these geomorphic menaces.

\subsection{Materials and methodology}

\subsection{SeCOndary Data SOURCE}

As a secondary data source the author has taken the help of several types of maps, i.e. topo-sheets (1:50000), police station (P.S.) maps (1:63360), block maps (1:50000), Calcutta plate 33 (1:100000), C.D.S. Maps (1:63360, 16 inches: 1 mile), satellite imagery, district planning maps. But these maps are not capable to capture the micro features of the study area. Being baffled to prominently classify the micro-level landform, a series of detail and intense (area basis) field works were conducted in 2002, 2004, 2012 and 2015. Beside the field surveys I have (the author) extracted the landuse data from the IRS P6 LISS II and LISS III. The spatial resolution is suitable for 1:50000 because landuse relates to the human activities associated with a specific piece of land, features present on the earth's surface (Lillesand and Kiefer 1987).

\subsection{PRIMARY DATA SOURCE}

Land survey was conducted with a Dumpy level and beside these the cross profiles of river were taken with the help of eco-sounder in the lower reach to prepare a bedcontour map. For the purpose of Dumpy level survey regional Bench Mark (BM) has been selected at Swarupnagar (Tentulia: 4m), Baduria (near Block Development Office: $3.14 \mathrm{~m}$ ) and Basirhat (near Basirhat Irrigation Office: 3.14m) (Ogdahl et al, 2014). The tidal velocities (low tide and high tidal velocity) were measured by an AA price current meter in a calm condition at two stations i.e. Basirhat (15/08/2015) and Tentulia (16/08/2015). All the cross sections were not confined in the river channel from bank to bank, rather extended $500 \mathrm{~m}$ on both sides of the channel.

\subsection{Mathematical and Statistical techniques}

For classification of landforms I have used the second order derivative (Wood, 1996), to calculate the rate of change of the form, such as the length of the river (x), the width of the river or channel (y) and height of the landforms (z). I have classified 
the land forms as, meander scar or meander scroll $\left(\mathrm{d}^{2} \mathrm{z} / \mathrm{dx}^{2}>0\right.$, $\left.\mathrm{d}^{2} \mathrm{z} / \mathrm{dy}^{2}=0\right)$, channel $\left(\mathrm{d}^{2} \mathrm{z} / \mathrm{dx}^{2}<0, \mathrm{~d}^{2} \mathrm{z} / \mathrm{dy}^{2}=0\right)$ and also flood plain $\left(d^{2} z / d x^{2}=0, d^{2} z / d y^{2}=0\right)$ (Wood, 1996) (Figs.1 and 2).

$$
d^{2} z / d x^{2}=d(d z / d x) / d x
$$

where, $d z / d x=d z / d y . d y / d x$

(For first meander scroll/ point bar)

Or, $\quad 1 / \mathrm{dy} / \mathrm{dx} \cdot \mathrm{dy} / \mathrm{dx}$

$$
\mathrm{d}^{2} \mathrm{z} / \mathrm{dy}^{2}=\mathrm{d}(\mathrm{dz} / \mathrm{dy}) / \mathrm{day}
$$

where, $\mathrm{dz} / \mathrm{dy}=1 / \mathrm{day} / \mathrm{dz}$

(For first meander scroll/ point bar)

And, $\quad d^{3} \mathrm{z} / \mathrm{dx}^{3}>0, \mathrm{~d}^{3} \mathrm{z} / \mathrm{dy}^{3}=0$ (3)

(for the second meander scroll)

For justification of the classification of the landforms, I have used the ANOVA one way to calculate the F factor, which is based on the difference between the data group $\left\{\mathrm{n}_{1}\left(\mathrm{x}_{1}-\mathrm{x}\right)+\mathrm{n}_{2}\left(\mathrm{x}_{2}-\mathrm{x}\right)+\mathrm{n}_{\mathrm{n}}\left(\mathrm{x}_{\mathrm{n}}-\mathrm{x}\right)\right\}$ and within the data group $\left\{\left(n_{1}-1\right) s_{1}^{2}+\left(n_{2}-1\right) s_{2}^{2}+\left(n_{n}-1\right) s_{n}^{2}\right\}$. The abbreviations of the different terms of ANOVA are, standard deviation (s), mean of each group $(\overline{\mathrm{A}})$, mean of the whole sample (X), sum square between group (SSB) and sum square within the group (SSE/SSW), degree of freedom (df), mean square (MS), total sum square (SST), a number of groups $(\mathrm{K})$ and number of samples (n).

\subsection{Study area}

\subsection{LOCATION}

The study area, geographically includes the Indian portion of the middle Ichamati river (Kalanchi to Basirhat bridge) and covers an area of about 1884.96 sq $\mathrm{m}$. Geographically the area is situated between $22^{\circ} 10 / \mathrm{N}$ to $23^{\circ} 11 / \mathrm{N}$ of Latitudes and $88^{\circ} 37 / \mathrm{E}$ to $89^{\circ} \mathrm{E}$ of Longitude (Fig. 1 and 2 )

\subsection{GEOLOGY}

The study area belongs to the district of North 24 Parganas of West Bengal, situated in the southern part of Bengal Basin. The Bengal Basin is a percartonic basin (Basu and Sil 2000). The Bengal Basin was formed by a chain of fluvio-tectonic actions (Sengupta 1996). The subsurface geology of the study area is completely blanketed by the quaternary sediments comprising a succession of silty-clay and sand of various grades, and sand mixed with occasional gravels and thin intercalations of silty-clay (Sikdar and Sahu 2009).

\subsection{Climate}

The study area is under tropical climate. The area receives maximum rainfall during the monsoon period (average monthly rainfall is $959.4 \mathrm{~mm}$ ). In Basirhat region, there is an average yearly rainfall is $231.8 \mathrm{~mm}$. The area is highly densely populated. People are by and large agriculturist here.

\subsection{Result}

The study area belongs to the deltaic plain of West Bengal. So, there are little variations of landform in the study area. The northern portion of the study area is under the mature deltaic plain, whereas the middle and lower portion is under the active deltaic plain. The mature part of the delta is going to be hydrological moribund because of the less active tidal action of the rivers and the rivers become choked with shoals and islands indeed. The degeneration of many of the channels has been progressed by natural maturity and human interferences (Bagchi and Mukherjee, 1978).

\subsection{VARIATIONS OF THE HEIGHT}

More than half of the study area is lying below 3-m contour line. The general slope of the study area is uniformly

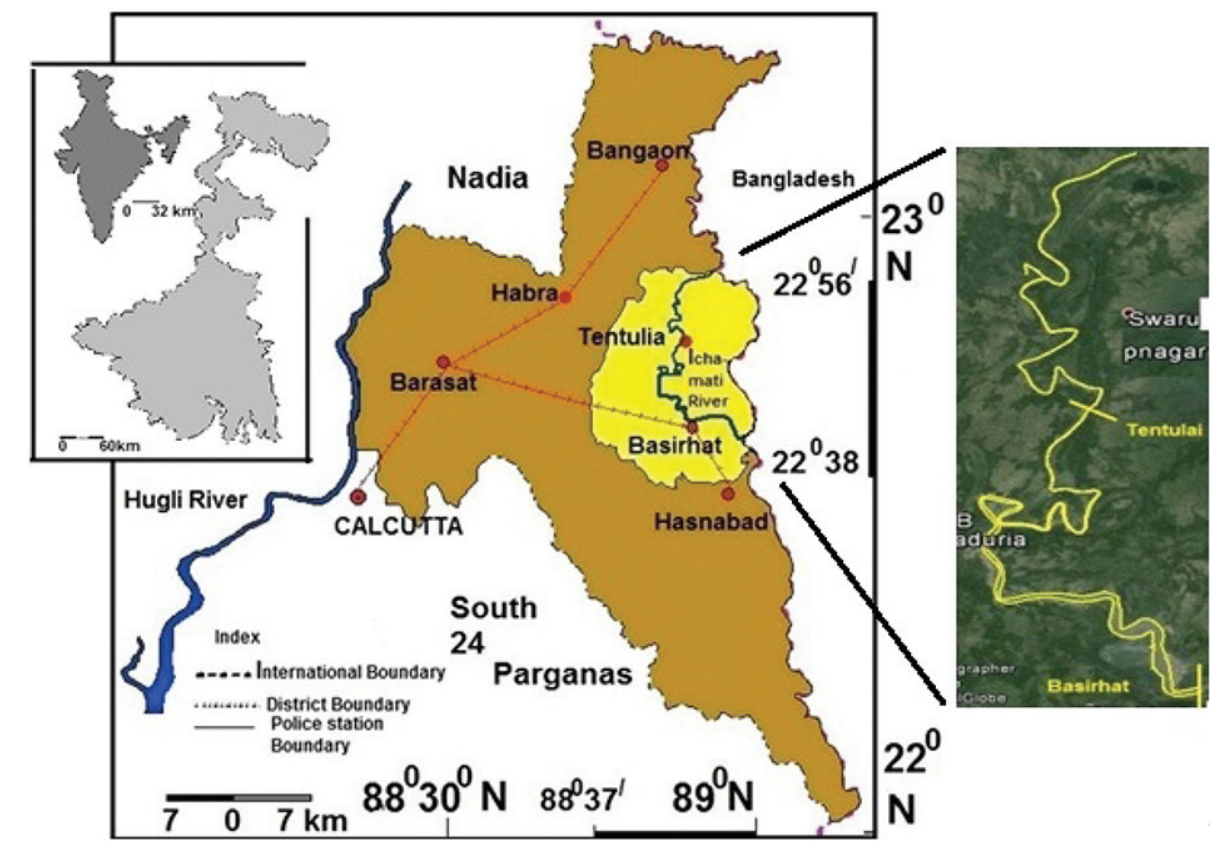

Fig. 1: the study area

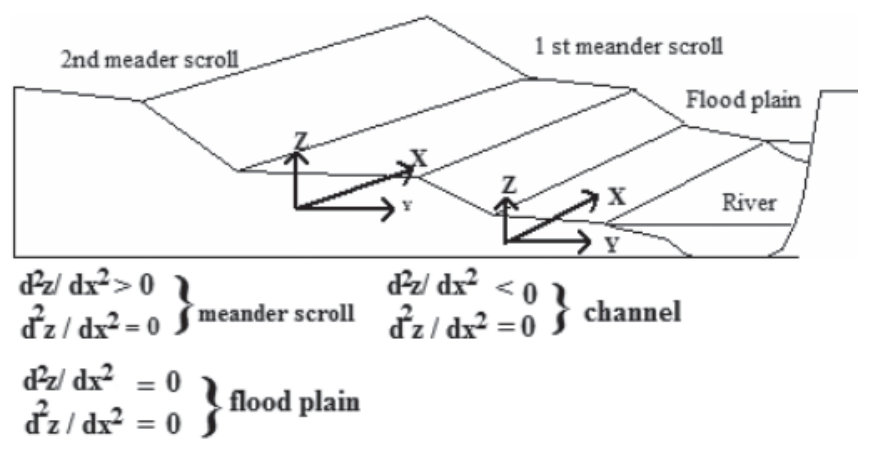

Fig.2: Derivative of different types of land forms (modified concept of Wood 1966) 
towards the coastal belt from the north to the south. The highest part is in the north of the study area which is dotted by stretches of moribund rivulets in Habra and Baduria police station and sand marshes in Swarupnagar and Basirhat police station. Some finger-like extensions of the higher areas have penetrated into the study area (Bagchi and Mukherjee, 1978).

\subsection{LANDFORMS IN THE STUDY AREA}

Every individual landform has certain assemblage properties (Fryirs 2016) and it is the outcome of the efforts of the adjustment of the river (Brunsden 1993, Florsheim et al. 2013). The landforms on the deltaic plain can be grouped into two classes, i.e. (a) land form on surface and (off channel landforms) (b) landforms in the channel (on channel landforms). Here the attempt is to classify the aforesaid landforms based on scale

TABle 1: Classification OF THE LANDFORMS

\begin{tabular}{llc}
\hline \multicolumn{1}{c}{ Classes } & \multicolumn{1}{c}{ Types of landforms } \\
\cline { 2 - 3 } & \multicolumn{1}{c}{ Meso-scale } & Micro-scale \\
\hline $\begin{array}{l}\text { Landforms on the } \\
\text { surface (Off channel } \\
\text { landforms) }\end{array}$ & $\begin{array}{l}\text { Flood plain, levee, } \\
\text { abandons channel fill } \\
\text { landforms, oxbow lake, } \\
\text { back swamp, river } \\
\text { channel }\end{array}$ & Meander scroll, \\
Landforms in the \\
$\begin{array}{l}\text { channel (On channel } \\
\text { landforms) }\end{array}$
\end{tabular}

Source: Classified by the researcher.

\subsubsection{Landforms on the surface (off channel landforms) \\ 4.2.1.1 Natural levee}

The natural levees act as dry point settlement and discontinuously run parallel with the Ichamati river. It has been highly modified and tough to identify even through close investigation. There are a number of villages, developed on the natural levees in Swarupnagar police station. The names of the villages are Gobra (J.L. No.18), Taranipur (J.L. No.17), Pantapare (J.L. No.23), Nalbara (J.L. No.22), Sarapul (J.L. No.36), Malangapara (J.L. No.37), Bangalani (J.L. No.38), Kabilpur (J.L. No.40). The average height of the natural levee is about $1.5 \mathrm{~m}$. The slope of the natural levee varies from place to place $\left(5^{\circ}-6^{\circ}\right)$.

\subsubsection{Oxbow lakes}

Oxbow lakes are classified as the inland water body (baor), having an immense ecological significance. Most of the oxbow lakes are gradually filled up by the transported topsoil of the adjacent agricultural lands during the rainy season. Paddy and jute are mostly cultivated here due to sufficient water supply. The important baors are Beri baor (N22 53/42//, E88 52/30//), Malangapara baor (J.L. No. 37, Swarupnagar P. S). In Baduria, Polta village (J.L. No. 99, Basirhat P.S.) is surrounded by an old abandoned channel. It is a comparatively low land and highly modified by human activities and followed by intensive paddy cultivation (Fig.3).

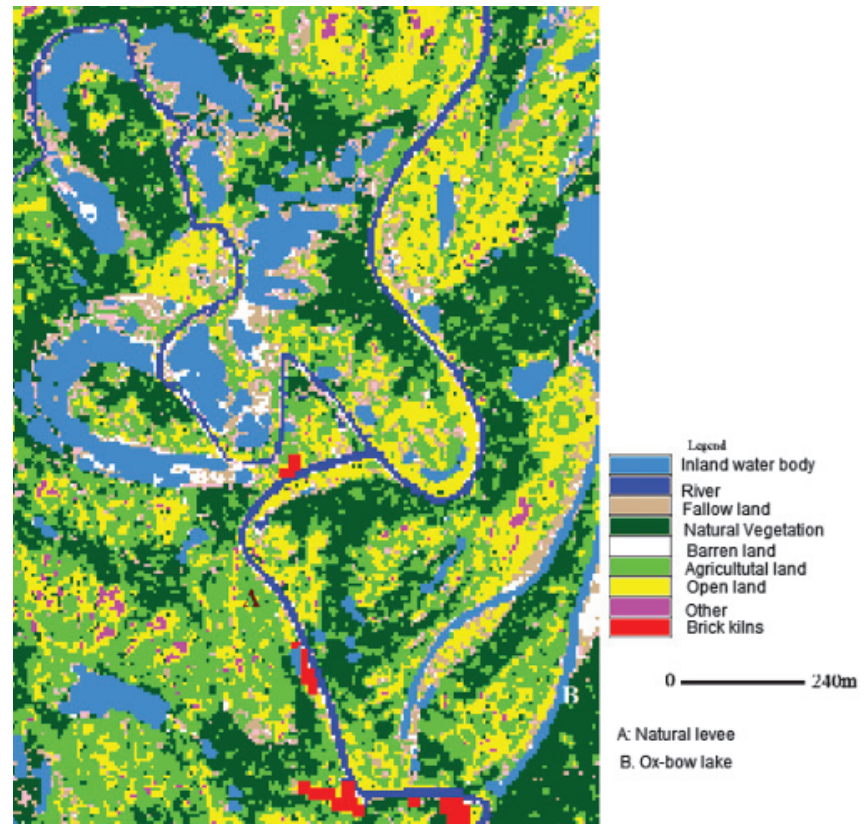

Fig.3(a): Different colours shows different land uses, but landforms are not identified here (Location; E88 49 / to E88 $51 / 76 / /$, N22 49 / to $22^{\circ} 51 / 54 / / \mathrm{N}$

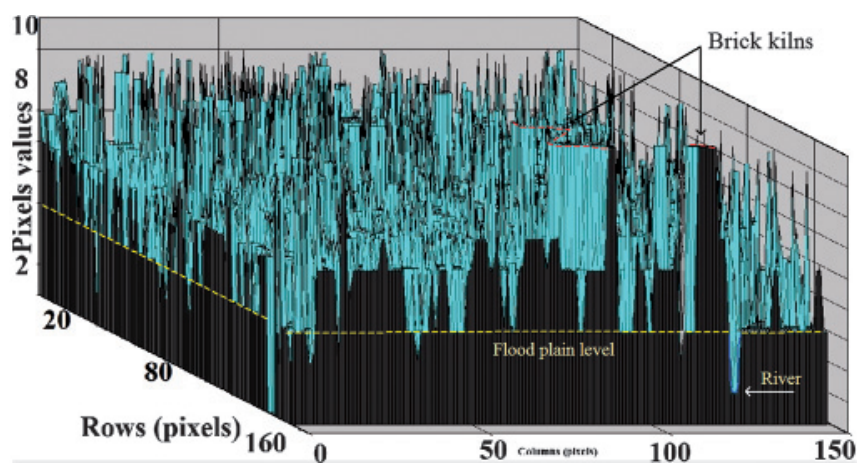

Fig.3(b): 3D DEM profile shows flood plain with the river having no variation

\subsubsection{Meander scrolls}

Meander scrolls or meander scars (Thornbury 1998) are the signature of the channel shifting. Another way, it denotes the threshold condition, river exceeded the old flood plain and meander scrolls occur (Nansen 1986; Magilligan 1992). The 3D DEM picture does not indicate any significant variation of the landform (Fig.3(a), (b)).

A meander scar consists of two elements: (a) plain floor: variable width, and (b) backside steep wall. In the study area, the meander scars appear as a pseudo-terrace like landform. The older meander scar is situated on the higher elevation and demarcated by the older tree line. In Bhekutia village (J.L. No.24, Swarupnagar P.S.) there are two successive meander scars on both sides of the Ichamati river (Plate 1 and Fig.4). The river has shifted its position in different times, keeping its footprint as a meander scar, at different elevations (Fig.5). In Kabilpur, there are three successive meander scars on the 


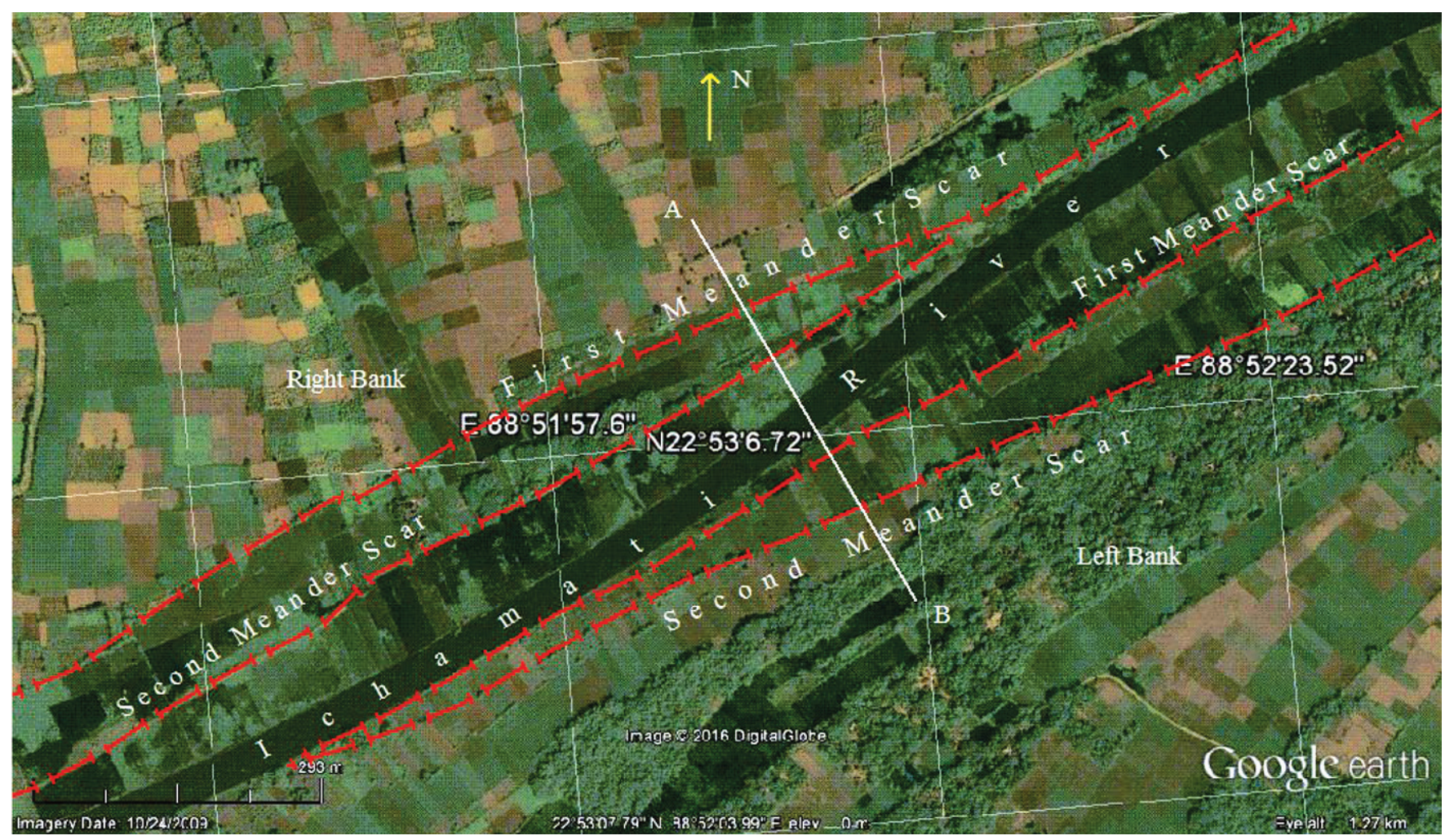

Plate 1: Position (red broken line) of the meander scars on the satellite image Data source: Google earth Pro version on 24/10/2002

Right bank (A) Left Bank (B)

Fig.4: Cross-section along the line A-B: variety of landforms with different crop combination Data source: Field survey conducted by the researcher on 31/12/2012

right bank of the Ichamati river. These three scars look steps like landforms having different extent, i.e., the 1 st scar (the oldest and upper most position): the average width is $270 \mathrm{~m}$, the 2 nd scar (the middle most position): the average width is $120 \mathrm{~m}$, the $3 \mathrm{rd}$ scar: the average width is $70 \mathrm{~m}$ and 4 th scar (the youngest and lowermost position): about 200m (Plate 2) (Figs.4 and 5). In the lower reach of the river, meander scar is absent. Because, in the lower reach, the both banks are arrested by anti-erosion measures taken by the brick kilns.

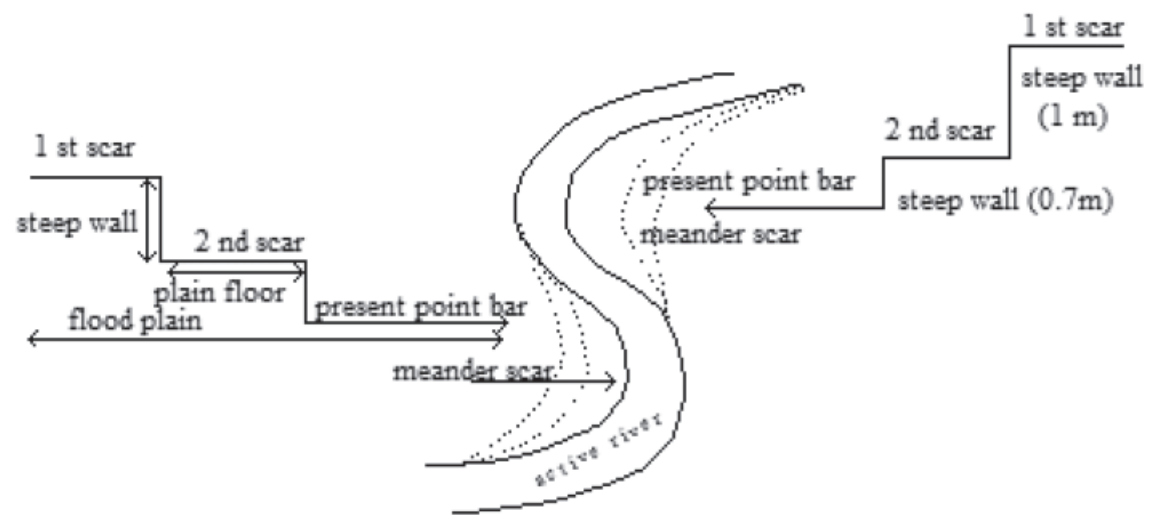

Fig.5: A model-representing the shifting position of meander scar based on Fig.4 
Different cropping pattern, practiced on the meander scrolls indirectly exhibit several hydrodynamic regimes. The upper meander scars are composed of comparatively coarse sand (medium permeability) and predominated by Rabi crop. The lower scrolls are composed of fine sand and predominated by paddy cultivation throughout the year (Fig.4). The river regimes shift from coarse sand to finer one. These indicate that the river lost its carrying capacity with time.

\subsubsection{LANDFORMS IN THE CHANNEL (ON CHANNEL LANDFORMS)}

\subsubsection{Point bars}

Convex bank of the river is characterized by point bar, mainly in the lower reach of the river. The area of the point bar has been decreased from the upstream downwards. The linear function between the area of the point bar and the distance along the river is $\mathrm{y}=5411 \mathrm{x}-13689\left(\mathrm{R}^{2}=0.264\right)$ (Fig.6). But the correlation of coefficient is high $(\mathrm{r}=0.514)$. During high tide these are submerged, but come into being with ebb period. Towards the upstream, the point bars are not well demarcated, but in the lower reach of the river the point bars are prominently developed. There are basic differences between the point bars of the upstream and the downstream reaches. First: the area of the point bars in the upstream is much lesser than those of the downstream. Second: the point bars in the upstream are composed of fine sand (photograph 1) but the point bars in the lower portion are composed of coarse sand (photograph 2).

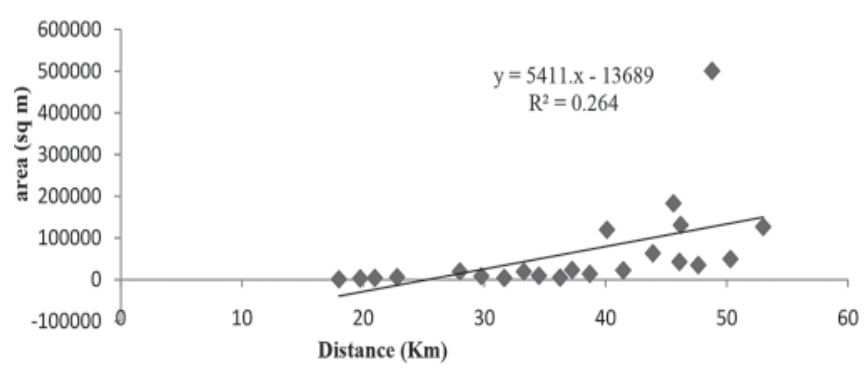

Fig.6: Relation between area of point bars and distance - area increases with distance

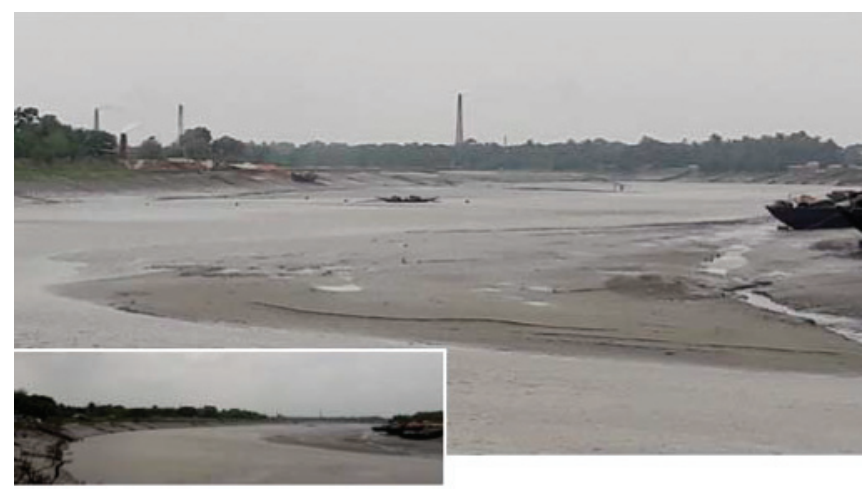

Photograph 1: Point bar on the convex bank (inset) at Fatullapur (J.L. No.88, Baduria P.S. Latitude: N22 42 /, Longitude: E88 $43 /$ ): Point bar is covered by thin alluvium with seldom ripple

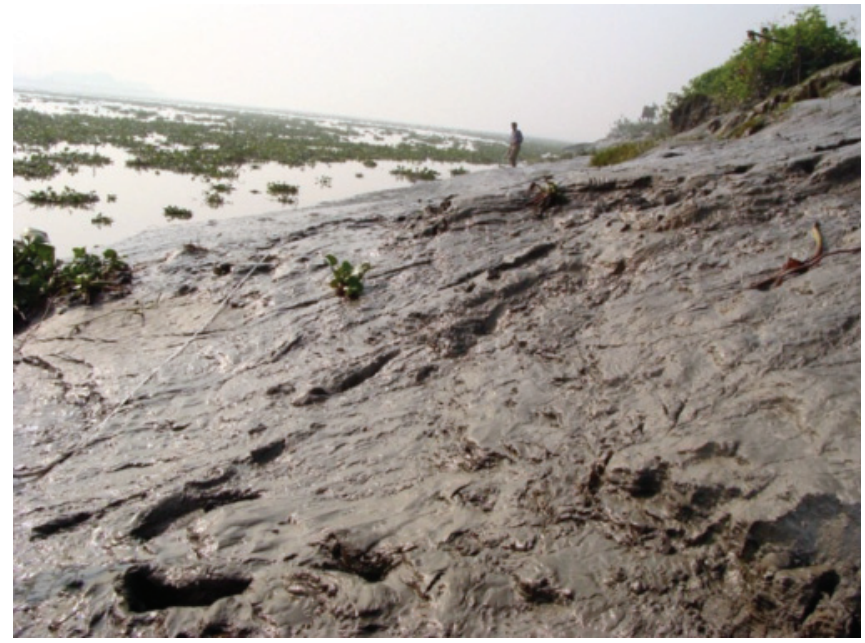

Photograph 2: Point bar at Harispur (J.L. No.40, Latitude: N22 ${ }^{\circ} 41 /$ and Longitude: E8851/): Lower portion of the point bar is composed of a thick (deep foot prints indicate that) unconsolidated material

\subsubsection{Ripples}

The point bars of the lower reach of the river are covered with ripples. The length of the ripple varies from $8 \mathrm{~cm}$ to $130 \mathrm{~cm}$. Ripples are mostly asymmetric in form (Fig.7). The downstream slope of the ripples are stepper than the upstream one (photograph 3 to 6). The ripples are mostly modified by two flow dynamics, e.g. (a) flow dynamic during high tide, and (b) flow dynamic during ebb period. As the ripples submerge during tides, its modification is beyond the observation.

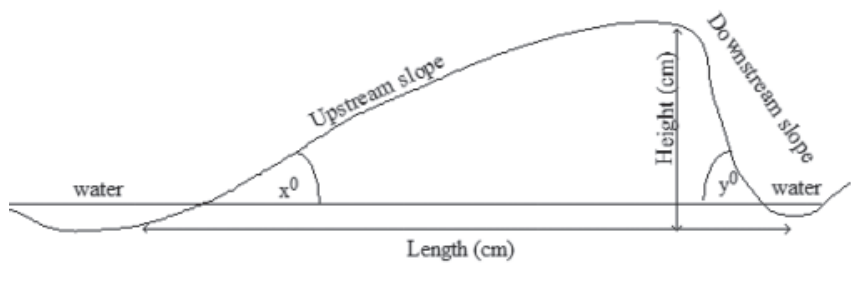

Downstream slope $\left(y^{0}\right)>$ Upstream slope $\left(x^{0}\right)$

$0 \longrightarrow 5 \mathrm{~cm}$

Fig.7: Graphical representation of a ripple of the Ichamati river at Harispur in Basirhat-I CD block

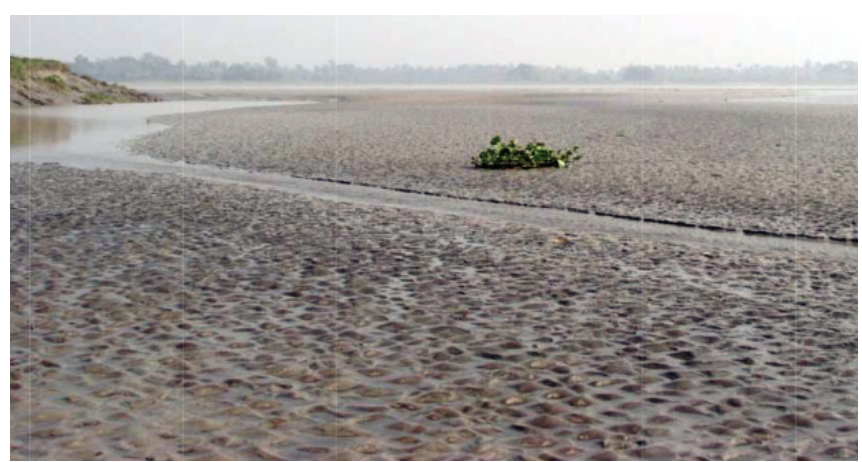

Photograph 3: Distribution of the ripples on a point bar at Harispur near Ferry ghat 


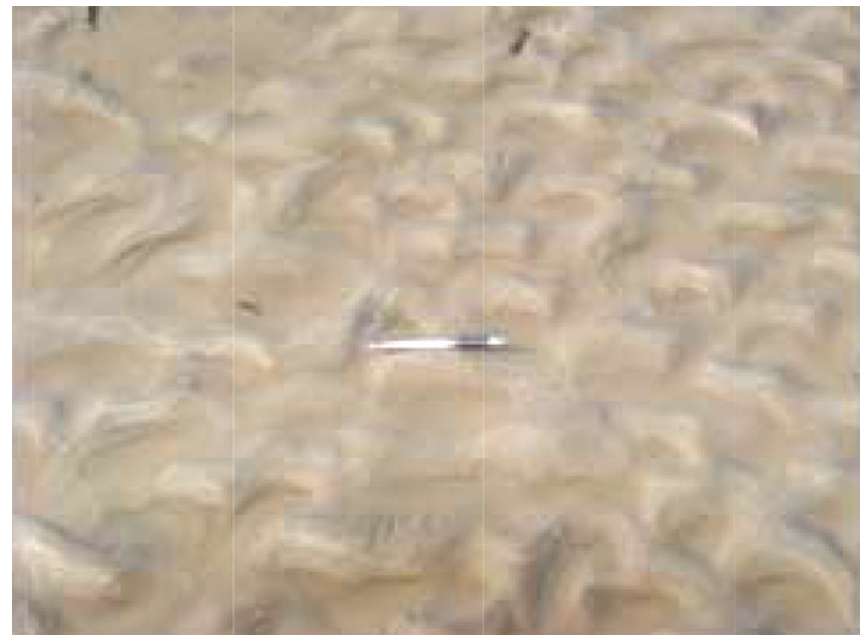

Photograph 4

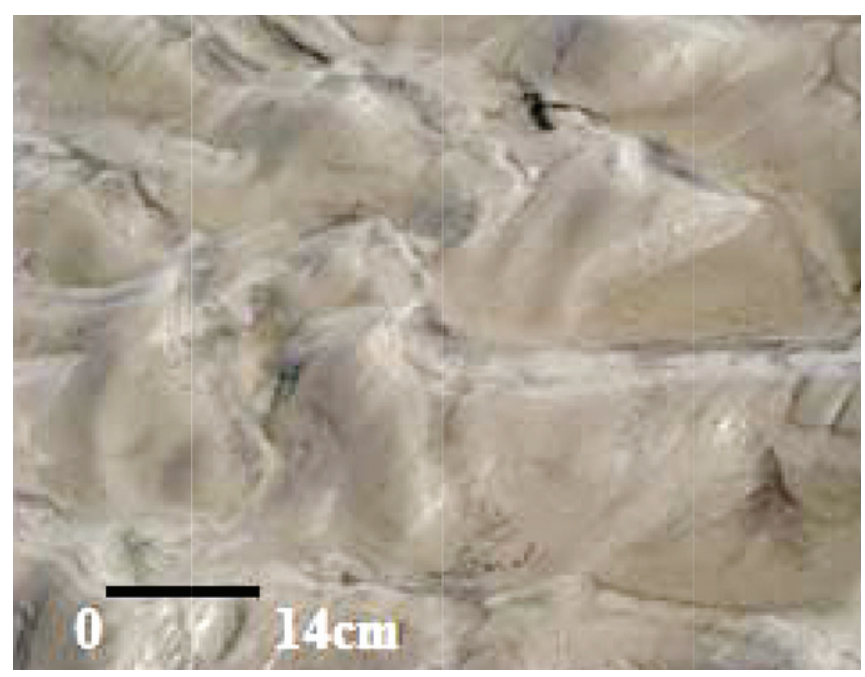

Photograph 5

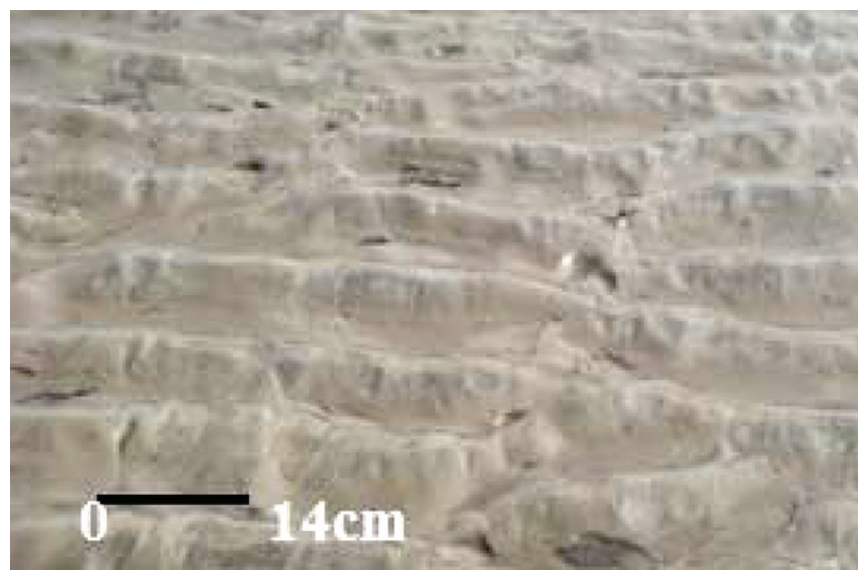

Photograph 6

Photograph 4 to 6: Different types of ripples at different places on the same point bar (Photograph 4.3)

Date: $26 / 12 / 2015$

\section{Discussions}

\subsection{POINT BAR: CLASSIFICATION AND JUSTIFICATION}

There is an ambiguity, whether the point bar would be classified as in-channel landforms or surface landform? Because high tidal level (HTL) divides the point bar into two distinct parts, one: a part under the water and another part is on the water. To analyse the classification of point bar, I have used two form elements such as width (y) and height (z) based on their area (x). So, the applicable equation, here, appeared as, $d^{2} z / d x^{2}=0, d^{2} z / d y^{2}=0$. For the second order derivation between height and distance, I have applied the polynomial function for more accuracy (error $=0.0001 \%$ ) rather than linear or other functions. Here the function $\{\mathrm{f}(\mathrm{x})\}$ is $0.000 x^{2}-0.105 x+5.395$, and $d^{2} z / d x^{2}=0.0001, d^{2} z / d y^{2}=0.0001$. These two values indicate the relief-less property of point bar. The undefined extent of the point bars and unconsidered gradient compensates the above slight error. I have applied two sets of the ANOVA test ( $\rho$-value $=5 \%$ for rejection the null hypothesis) for the justification of point bar classification, one test for the area (A) properties of the point bars and the other is for the ration of area of point bars and the width of the river (A: W). I have rejected the null hypothesis $\left(\mathrm{H}_{\mathrm{o}}\right)$ (there is no significant difference between the point bar) based on F-statistics ( $\mathrm{F}=$ significantly large). I have classified the 22 point bars into three groups according to area. The result of ANOVA test are, $\mathrm{SSB}=0.16, \mathrm{SSE}=$ 175920860000. The value of F-statistics are 0.00017 that indicates that the area properties have an insignificant impact on classification among the point bars (Table 1). The ANOVA test of the three groups of point bars (area: the width of the channel) shows a better result. The value of the SSB and SSE are 795 and 859622 respectively. The F-statistics factor (0.008) (Table 2) marks no significance in meander classification.

\subsection{MeAnder Scroll: Classification AND JUSTIFICATION}

The meander scroll has an immense impact on local landuse. The Ichamati is characterized by unpaired meander scroll in its middle course. The different meander scrolls are classified according to different height of their locations. I have also considered their width parameter. The value of the second order derivative of the height factor $(\mathrm{z})$ to the length factor $(x)$ is greater than zero (For first meander scroll: $\left.\mathrm{d}^{2} \mathrm{z} / \mathrm{dx}^{2}>0.012\right)$, and $\mathrm{d}^{2} \mathrm{z} / \mathrm{dy}^{2}=0$ ). For second meander scroll, $\mathrm{d}^{3} \mathrm{z} / \mathrm{dx}^{3}>0.022$ and $\mathrm{d}^{3} \mathrm{z} / \mathrm{dy}^{3}=0$. The ANOVA test also justified strongly this classification. The test was applied to the meander scrolls $(n=13)$ on the left side bank. The value of SSB is 5.28 and SSE is 7.35 (Table 2), successively. The value of the F-statistics is $8>>>0.05$ (Table 2), which strongly rejected the null hypothesis (meander scrolls are uniform in character). The relation between height and width of the meander scroll is moderately negative $(\mathrm{r}=-0.35)$.

\subsection{RIPPLE: CLASSIFICATION AND JUSTIFICATION}

I have taken into account 117 ripples in three stations, namely Basirhat, Harispur-Bibipur and Baduria region (Fig.8). 
TABLE 2: VALUeS OF ANOVA teST OF THE CLASSIFICATION OF DIFFERENT LANDFORMS

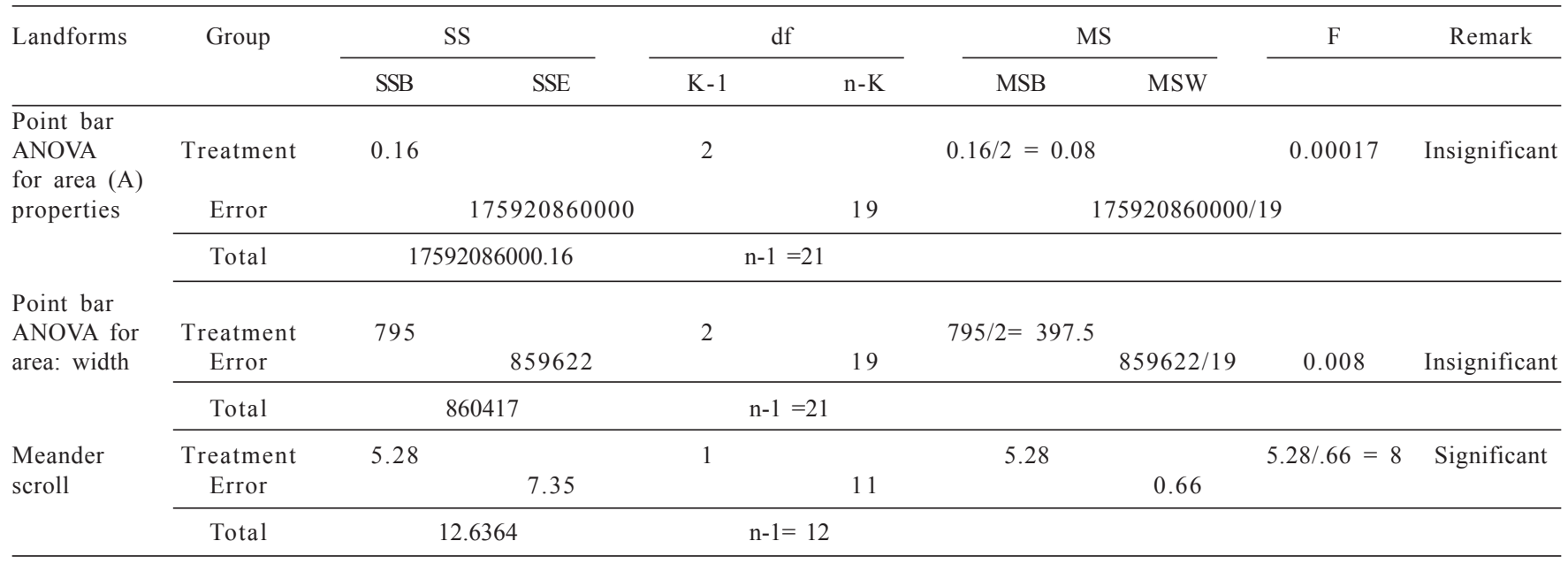

TABLE 3: ANOVA TEST FOR RIPPLE

\begin{tabular}{|c|c|c|c|c|c|c|c|c|c|}
\hline \multirow[t]{2}{*}{ Landform } & \multirow[t]{2}{*}{ Group } & \multicolumn{2}{|c|}{ SS } & \multicolumn{2}{|c|}{$\mathrm{df}$} & \multicolumn{2}{|c|}{ MS } & \multirow[t]{2}{*}{$\mathrm{f}$} & \multirow[t]{2}{*}{ Remark } \\
\hline & & SSB & SSE & $\mathrm{K}-1$ & $n-K$ & MSB & MSW & & \\
\hline \multirow[t]{3}{*}{$\begin{array}{l}\text { Ripple } \\
\text { (Micro-landform) }\end{array}$} & Treatment & 21392.9 & & 2 & & 10696.45 & & 21.82 & Significance \\
\hline & Error & & 55866.2 & & 114 & & 490.05 & & \\
\hline & Total & 77259.2 & & 116 & & & & & \\
\hline
\end{tabular}

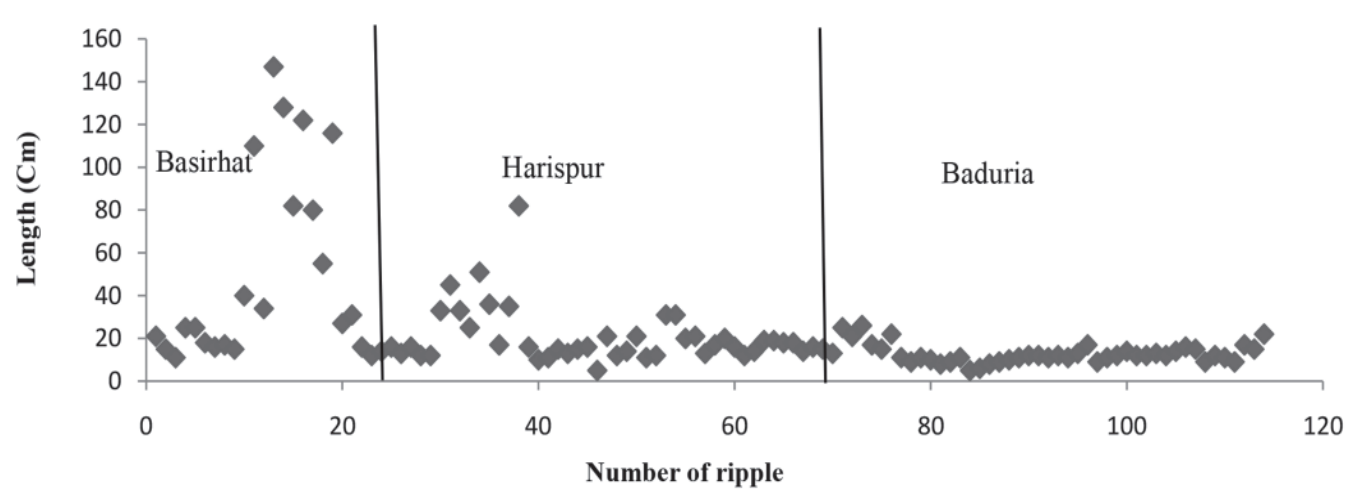

Fig.8: The pattern of length of ripples at different stations.
Beyond Baduria, the flow is not competent to form such micro level landforms on point bar. The velocity and specific energy of the river is gradually decreasing downstream upward (Mondal, et al. 2019). At every station I have taken 39 ripples for ANOVA test. Therefore, $\mathrm{K}$ will appear as 3 , here. The formula $\mathrm{d}^{2} \mathrm{z} / \mathrm{dx}^{2}>0, \mathrm{~d}^{2} \mathrm{z} / \mathrm{dy}^{2}$ $=0$ etc. are not applicable

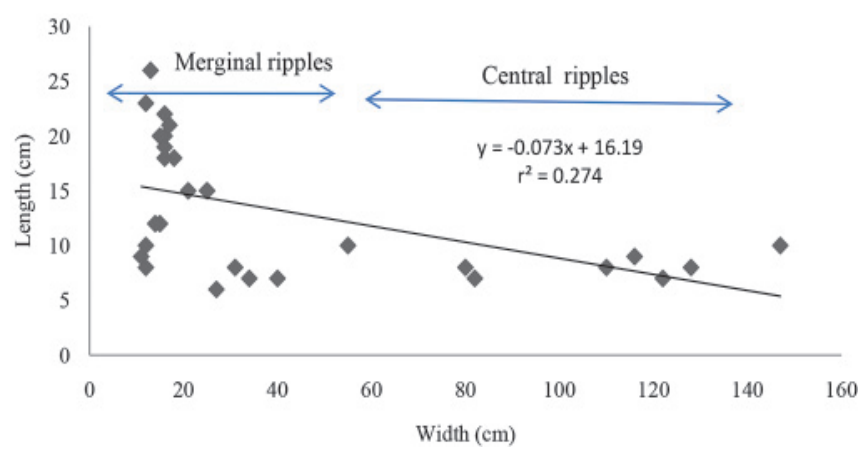

Fig.9: Relation between width and length of the ripples of the Ichamati river

Source: Data collected on $-3 / 06 / 2004$, on the point bars at Harispur and Basirhat for such micro features. For the justification of the above three classes, the value of SSB is 21392.9 and SSE is 55866.2 (Table 3 ). The value of the F-statistics is $21.82>>>0.05$ (Table 2 ), which is significantly high to cancel the null hypothesis. The length of the ripple has been decreased downstream upward.

There is also a remarkable local level variation of the ripple-size. The length-width ratio $(r=-0.523)$ shows that the larger size ripple are formed at the margin of the point bar, whereas the ripple on the central point bar comparatively smaller (Fig.9). Besides the above parameters, the slope ratio between two sides slopes (upstream $\left(\mathrm{U}_{\mathrm{s}}\right)$ and downstream $\left(D_{s}\right)$ ) of the individual ripple are not satisfactory $(\mathrm{r}=-0.17)$, also. 


\subsection{Conclusions}

An explanation for the classification of the landforms in the highly modified by human activities in the low relief deltaic region is proposed. The cross sections of the area, produced by DEM (based on IRS P6 LISS II and LISS III) do not identify any significant variations of the landforms. After the field investigations, the landforms of the area have been classified and ANOVA test has justified the classification. The oxbow lakes, natural levee are highly modified and converted to agricultural land and thus lost their geomorphic significance. Flood plain genetically converted from point bar and the point bars are attached to the flood plain on the convex bank and gradually extend toward the concave bank. So, there is no well defined demarcation line between flood plain, river bank, point bar and channel bed. Therefore, the low value of F-statistics (0.00017) justified such lack of clarification. On the other hand, the high value of the F-statistics $(\mathrm{F}=8, \mathrm{~F}=21.86)$ proves the right classification of meander scrolls and ripple. These classifications have brought the geomorphic truth before us as, (a) The river is enough capable to produce the prominent landforms such as point bars (area and distance relation: $r=0.514$ ), ripple (number and length decrease downstream upward) etc., (b) the agricultural practices on the meander scrolls are different due to sediment texture which indicates the change of river regime. The lower meanders are characterized by paddy cultivation throughout the year.' These landforms are comparatively young and composed of fine sediment, that for they have high water contain capacity. The series of coincidence indicates the river lost its carrying capacity with time. The present paper claims some detail data sources. Sediment character has been analyzed by feel method. An intensive sediment discharge record, bed load data may increase the quality of the paper. This lack may fill up subsequently to enhance the research quality.

\section{Acknowledgement}

I sincerely thank Prof. LN Satpati of the Department of Geography, University of Culcatta, Kolkata, for his valuable comments towards the completion of this article.

\section{Referrences}

1. Andrews E.D, Parker G. (1987): Formation of a coarse surface layer as a response to gravel mobility, in Sediment Transport on Gravel Bed Rivers, in C. R. Thorne, J. C. Bathurst, and R. D. Hey (eds.), John Wiley, New York: 269325, Angillieri MYE (2008) Morphometric Analysis of Colanguil River Basin and Flash Flood Hazard, San Juan, Argentina," Environmental Geology, 55 (1): 107-11

2. Bagchi K., Mukherjee K. N. (1978): Diagnostic Survey of Deltaic West Bengal, Calcutta: 46-75.

3. Basu B., Sil S. (2000): Arsenic Mapping for North 24Parganas District of West Bengal - Using GIS and Remote Sensing Technology, Map India Conference 2003, (C) GISdevelopment.net.
4. Basu S.R., Howlader K. (2008): Some Considerations on the Process of Sedimentation in the Ichamati tidal Channel, Geographical. Review of India, 70 (4): 369-380

5. Bisci C., Darmis F. (1991): II Concetto di attivita in geomorfologia, Geografis fisica a Dinamica Quaternaria 14(2): 193-199

6. Blaszezyneki J. S. (1997): Landforms characterization with geomorphic information systems photogrammetric engineering and remote sensing, 63 (2): 183-191.

7. Bloom A., et al. (1948): The equilibrium alluvial river under variable flow and its channel forming discharge, $J$. Geophys. Res.-Earth, 122, https://doi.org/10.1002/ 2017JF004213,201

8. Bloom A. L. (1991): Geomorphology; a systematic analysis of the Cenozoic landforms, Practice Hall, Upper Saddle river, $\mathrm{NJ}$

9. Brierley et al. (2013): Reading the landscape integrating the theory and practice of geomorphology to develop place based understandings of river systems, Process in Physical Geography 37(5): 601-621

10. Brunsden D. (1993a): Barriers to geomorphological change, In landscape sensitivity, Thomas DSG, Allison RJ (eds), John Willey \& Sons, Chichester.

11. Castaldini D et al. (2009): Geomorphological and geoaourist maps of the Upper Tagliole Valley (Modena Apennines, MNorthen Italy), In: P. Coratza, M. Panizza (eds), geomorphology and Cultureal Heritage - Geomorphologia beni culturali, memorie descrititive delta carta geologica d'Italia 87/2009:29-38

12. Chorley et al. (1984): Geomorphology, Methuen and Co. Ltd, London, New York: 605

13. Davis M. (1909): The Geographical cycle, Geogr. J.

14. Dawkins R. (2004): Extended phenotype - but not too extended, Biology and Philosophy 19; 377-396

15. Delcourt H. R., Delcourt P. A. (1988): Quaternary landscape ecology; relevant scales in space and time, Landsc Ecol 2(1): 23-44

16. Dietrich W.E., Perron J. T. (2006): The search for a topographic signature of life, Nature, 439: 411-418

17. Flint J. J. (1974): Stream gradient as a function or order magnitude and discharge, water resource Res., 10. 969-973, https://doi.org/10.1029/WR010i005p00969.

18. Florshei et al. (2013): Thresholds of satability in incised "Anthropocene" landscapes, Anthropocene 2

19. Ford et al. (1998): Spaceborne radar observations, a guide for Magellan radar-image analysis, JAL publication 89-41, Pasadona

20. Fryirs K. A. (2016): River sensitivity: a lost foundation concept in fluvial geomorphology, Earth Surface processes and landforms, DOI:10.1002/esp.3940

21. Garavaglia et al. (2010: Influence of climate change on geo diversity in the Alpine environment: the case of two Italian 
glacier investigated through dendrochronology, Geomorephologie, relief, processus, environment 2: 153-164

22. Goudie A.S. (2004): Encyclopedia of geomorphology, Routledge, London, UK

23. Hack J. T. (1973): Stream Profile Analysis and Gradient Index. Jour. Research U.S. Geol. Survey, Vol.4 (4): 421-429.

24. Hey R. D. (2006: Fluvial Geomorphological Methodology for Natural Stable Channel Design. Journal of the American Water Resources association (JAWRA): 358

25. Lane E.W. (1955): The importance of fluvial morphology in hydraulic engineering, Proc. Am. Soc. Civ. Eng., 81, 1-17.

26. Lane S.N., Richards K.S. (1997): Linking river channel and process; time, space and causality revisited, Earth Surface processes and landforms 22:

27. Langbein W.B., Leopold L.B. (1966): River Meanders Theory of Minimum Variance. US Government Printing Office, Washington, D.C. 20402. H2,

28. Langbein W., Leopold L.B. (1964): Quasi-equilibrium States in Channel Morphology. Amer. Jour. Sci. 262: 782 94.

29. Leholsky M., Greskova A. (2007): Fluvial Geomorpohlogical Approach to River Assessment Methodology and Procedure. Geograficky Casopis, 59, 2, 22tabs.

30. Lehotsky M., Novotny J. (2004): Morfologické Zóny Vodných tokov Slovenska. Geomorphologia Slovaca, 4(2), 48-53

31. Leopold et al.(1964): Fluvial Processes in Geomorphology. Eurasia Publishing House (Pvt.) Ltd., Ram Nagar, New Delhi: 55,131-322, 411-474

32. Leopold L.B., Langbein W.B. (1962): The Concept of Entropy in Landscape Evolution. U.S. Geological Survey. Prof. Paper 500-A

33. Lillesand T.M., Kiefer R.W. (1987): A Case Study of Nalanda District, Bihar, Inter-India Publications, New Delhi: 1

34. Mackin J. H. (1948): Concept of the graded river, Geol. Soc. Am. Bull., 59, 463-511,

35. Magilligan F. J. (1992): Threshold and satial variability of flood power during extreme floods, Geomorphology 5.

36. Marchant D.R., Head J.W. III. (2007): Antartic dry valleys: microclimate zonation, variable geomorphic process and implications for assessing climate xhange on Mars, Icarus, 192:187-222

37. Matthews et al. (2014): Under construction; an operational bridge between ecology, evolution, and ecosystem science, Ecological Monograph 84;245-263

38. Mesa L.M. (2006): Morphometric Analysis of a Subtropical Andean Basin (Tucumán, Argentina), Environmental Earth Sciences, Vol. 50(8): 1235-1242
39. Mondal M. (2011): Long Profile of the River Ichamati and Intervention of Man. Practicing Geographer, Vol.15 (1), Kolkata: 59-83.

40. Mondal L., Bondhyopadhyay J. (2014a): Environmental change of transinternational boundary Indo-Bangaladesh bordae of Sundarban Ichamati river cxatchmant area using geoinformatics techniques, W. B., India, Univ J Environ Res Tech 4(3)

41. Mondal L., Bondhyopadhyay J. (2014b): Morphodynamic change of the Ichamati river and land use/ landcover changes through space and time using remote sensing and GIS techniques N24 Parganas, W. B., India (Bagdah, Bongon, Gaighata and Swaru[ngar Block), Hyderabad, India

42. Mondal M. (2010): Bank erosion of the Ichamati river in Swarupnagar and Baduria Blocks, N 24 pgs, W., B.: Its Geomorphic Significance and Some Associated Problem. Indian Journal of Landscape Systems and Ecological Studies. Vol.-33(2) Kolkata: 793-800.

43. Mondal M. (2011): Bank Erosion of the Ichamati river: The hazard, its Management and Land Resource Development in Swarupnagar and Baduria CD Blocks of North 24 Parganas District, W. B. Geographical Review of India. Vol.-73., No.4, Calcutta: 391-399.

44. Mondal M. (2012): Morphodynamics Setting and Nature of Bank Erosion of the Ichamati river in Swarupnagar and Baduria blocks, 24 Parganas (N), W.B. Indian Journal of Spatial Science.Vol.-3 (1\&2): 35-43.

45. Mondal et al. (2016): Character of Cross - Profiles with respect to the Optimum Channel cross sections in the Middle reach of the Ichamati River of West Bengal, India. Transactions, Vol.38 (2) : 201-214.

46. Mondal M., Satpati L.N. (2018): Optimum cross section index (OCI): a new approach for identification of an optimum channel: A case study of the Ichamati River, India. Arabian Journal of Geosciences, 11, 333,https:// doi.org/10.1007/s12517-018-3667-3

47. Mondal M., Satpati L.N. (2019): Human intervention on river system: a control system - a case study in Ichamati River, India, Environment, Development and Sustainability, Springer Nature, (2020): 22:5245-5271, https://doi.org/10.1007/s10668-019-00423-3

48. Mondal M., Satpati, L..N. (2015): Long Profile Analysis of Ichamati River With the Help of Best Fit-Curve, India, Indian Journal of Geomorphology, Vol. 20 (2): 109-124.

49. Mondal M., Satpati, L.N. (2013): Evaluation of the Character of Long Profile vis-à-vis Discharge Patterns of the River Ichamati in a Selected Stretch of North 24 Parganas District, India, Indian Journal of Power and River Valley Development, 63, 11-12: 183-188.

50. Mondal M., Satpati, L.N. (2014): Morphodynamic Variables and Character of the Long Profile of Ichamati 
river in North 24 Parganas District of West Bengal, Geographical Review of India. Vol.-76 (4), Calcutta: 347-359.

51. Mondal M., Satpati, L.N. (2016): Changing Character of Pool-Riffle Sequence: A Quantitative Representation of Long Profile of Ichamati, India. Indian Journal of Power and River Valley Development, Vol. 66 (1\&2): 14-21.

52. Mondal M., Satpati, L.N. (2017): Hydrodynamic character of Ichamati: impact of human activities and tidal management (TRM), W.B., India. Indian Journal of Power \& River Valley Development, 67(3-4)

53. Mudd et al. (2018): How concave are river channel? Earth Surf. Dynam. 6. 505-523, https://doi.org/10.5194/esurf-6505-2018

54. Nanen G.C. (1986): Episodes of vertical accretion and catastrophic stripping: a model of disequilibrium flood plin development, Geological Society of America Bulletin 97(12).

55. NEH-2007 US Department of Agriculture: Basic Principles of Channel Design, Chapter-7, Part-654, National Engineering Hand Book

56. NSSH (2009): National soil survey handbook, part 629, Glossary and Landform and geologic terms

57. Parker G, Sutherland AJ (1990): Fluvial Geomor. J. Hydraul. Res., 28 (5): 529-544

58. Penck W. (1924): Die morphologische analyse, Geologie Geog. Abh. 2 Reihe, heft 2 stutgrt, Engelhorn

59. Phillips D.J. (2015): Landforms as extended composite phenotypes, earth Surf. Process. Landforms, John Wiley and Sons Ltd., doi: 10.1002/esp.3764

60. Phillips D.J. (2009a): Soils as extended composite phenotypes, Geoderma 149:143-151.

61. Pike R.J. (2000): Geomorphometry - diversity in quantitative surface analysis, Process in Physical Geography 24(1): 1-20

62. Richard K. S. (1982:) Rivers, Form and Process in Alluvial Channels. Methuen, London.

63. Rosgen D. L. (1994): A Stream Classification System, Catena, Vol. 22169199, Elsevier Science, Amsterdam.

64. Royden et al. (2000): Evolution of river elevation profiles by bedrock incision: analytical solutions for transient river profiles related to changing uplift and precipitation rates in EOS, Transactions of the American Geogpysical union, vol. 81, Fall Metting supplement

65. Rudra K. (2014:) Changing River Courses in the Western Part of the Ganga-Brahmaputra Delta. Geomorphology 227, 87-100.

66. Sarkar A. (2004): River Bank Erosion: Geomorphology and Environment, acb publications, Kol: 87, 97, 95

67. Sen P.K. (1993): Geomorphological Analysis of Drainage Basins, .University of Burdwan. Burdwan
68. Sengupta S. (1966): Geological and geophysical studies in western part of Bengal basin, India, Bulletin, American Association of Petroleum Geologists, 50(5): 1001-1017.

69. Sikdar P.K., Sahu P. (2009): Understanding Wetland Subsurface Hydrology Using Geology and Isotopic Signature, Hydrology Earth System, Sci., 13, 1313 -1329.

70. Slaymaker et al. (2011): Geomorphology and global environment change, Cambridge University Press.

71. Small R. J. (1978): The study of landforms: A text book of geomorphology, Cambridge university press

72. Spagnolo M. , Frank J. P. (2005): Testing the geological influences on the evolution of river profiles: a case from the Northen Apennines (Haly), Geigr. Fis. Dinam. Quat. 28 (2005), 103-113, bfigg.2tabb.

73. Sparks B.W. (1960): Geomorpohology, Longmans Green, London., 76-99.

74. Strahle A.N. (1957): Quantitative Analysis of Watershed Geomorphology, Transactions - American Geophysical Union, Vol. 8 (6): 913-920

75. Strahler A.N. (1969): Physical Geography, $3^{\text {rd }}$ edition, John Wiley and sons. Inc. New York: 441-496.

76. Strahler A.N. (1964): Quantitative Geomorphology of Drainage Basin and Channel Networks," In: V. T. Chow, Ed., Handbook of Applied Hydrology, McGraw Hill Book Company, New York.

77. Summerfield M. (1991): Global geomorphology, Practice Hall, Upper Saddle river, NJ

78. Thornbury W.D. (1998): Principles of Geomorphology: Wilel Eastern Ltd. New Delhi. 99-175.

79. Thorne C.R. (1978): Processes of Bank Erosion in River Channels, Unpublished Ph.D. thesis, University of East Anglia: 447

80. Wheelwwr D.A. (1979): The overall shape of longitudinal profiles of stream in Pity, A. F. (eds.) Geomorphological Appreoaches to Fluvial Process, Norwich, Geobooks: 24160.

81. Whipple K.X., Tucker G.E. (2002): Implications of sediment-flux-dependent river incision models for landscape evolution, J. Geophys. Res.-Sol. Ea., 107, 2039, https://doi.org/10.1029/2000JB000044

82. Wilcock.PR., Southard J.B. (1989): Bed load transport of mixed size sediment: Fractional transport rates, bed forms, and the development of a coarse bed surface layer, Water Resour. Res., 25: 1629-1641,

83. Williams G.P. (1978b): Hydraulic geometry of river cross section theory of minimum variance, professional paper, US Geolozi. Survey, 1029.

84. Wooldridge S.W., Morgan R.S. (1959): An outline of Geomorphology -The physical basis of Geography, orient Longman Ltd, 17, CR Avenue, Kol-72. 